\title{
SOUTH KOREAN LEADERS IN THE POLITICS OF DEMOCRATIZATION
}

\author{
Grażyna STRNAD \\ Jagiellonian University \\ Faculty of International and Political Studies \\ ul. Gronostajowa 3 \\ 30-387 Kraków \\ grazyna.strnad@uj.edu.pl
}

\begin{abstract}
This article aims to show the process of formation and operation (functioning) of the changing political system of South Korea. It is undertaken for the analysis of the process of the collapse of the former authoritarian political system and formation of South Korean democracy. Indicated in this article are the roles and participation of political leaders (Chun Doo Hwan, Roh Tae Woo, Kim Young Sam, and Kim Dae Jung) in the process of intense political change that took place in South Korea from the 1980 s to the late twentieth century.

During the authoritarian regimes of South Korea, the nation recorded spectacular economic development, but without political development. Political leadership in the democratization of the country was still authoritarian. Core values and attitudes of politicians pointed to the presence of the cultural heritage of Confucianism in politics.
\end{abstract}

Key words: South Korea, democracy, democratization process, political leaders, Confucian leadership 


\section{POLUDNIOWOKOREAŃSCY LIDERZY W POLITYCE DEMOKRATYZACJI}

Streszczenie: Artykuł ma na celu ukazanie procesu kształtowania się i funkcjonowania zmieniającego się systemu politycznego w Korei Południowej. Podejmowana zostaje analiza procesu upadku autorytarnego systemu politycznego i formowanie się południowokoreańskiej demokracji. Wskazano na rolę i uczestnictwo liderów politycznych (Chun Doo Hwan, Roh Tae Woo, Kim Young Sam, Kim Dae Jung) w procesie intensywnych zmian politycznych, które miały miejsce w Korei Południowej pod koniec lat $80 \mathrm{XX}$ wieku.

W okresie autorytarnych rządów Korea Południowa odnotowała spektakularny rozwój gospodarczy, jednak nie towarzyszył temu rozwój polityczny. Przywództwo polityczne w demokratyzującym się państwie nadal pozostawało autorytarne. Ponadto wyznawane wartości i postawy polityków wskazywały na obecność kulturowego dziedzictwa konfucjanizmu w polityce.

Słowa klucze: Korea Południowa, demokracja, proces demokratyzacji, liderzy polityczni, konfucjańskie przywództwo

\section{민주화 투쟁시기 한국의 정치 지도자들}

개약: 본고의 목적은 한국의 변화하는 정치 체제의 형성과 운영(기능)과정을 보여주는 것이다. 이 연구는 전독재정치체제가 붕괴되고 남한민주주의가 형성되는 과정을 분석하기 위해 착수되었다. 본 연구서는 1980년대부터 20세기말까지 한국에서 일어난 치열한 정치적 변화 과정에서 정치지도자 (전두환, 노태우, 김영삼, 김대중)의 역할과 참여가 검토된다. 독재정권시대에 한국은 놀라운 경제발전을 기록했지만 정치발전은 없었다. 국가의 민주화에서 정치적 리더십은 여전히 독재적이었다. 정치가의 핵심 가치와 태도는 정치에서 유교의 문화유산이 존재함을 지적했다.

키워드: 한국, 민주주의, 민주화과정, 정치지도자, 유교리더십

\section{South Korean Democracy - The Negotiated Compromise}

South Korea for many years was considered one of the poorest agricultural countries in the world. Since 1962, it increasingly became a place of rapid industrialization, and by the end of the nineteen 
eighties had achieved the status of a newly industrialized country. Seoul's economic success has been called "economic miracle on the Han River", which has become the key to the international promotion of South Korea. The spectacular economic development, which appeared during the period of authoritarian rule, however, was not accompanied by political development.

The process of democratic change in the system did not start due to a gradual collapse of the government of President Chun Doo Hwan. Since the nineteen eighties, the formerly authoritarian political system of the Republic of Korea has, in fact, been unable to solve socio-political problems resulting from changes in South Korean society. South Korean political transition became possible as a result of a negotiated compromise pact between the political elites of the authoritarian governments of Chun Doo Hwan and Roh Tae Woo, with the democratic opposition (Kim Young Sam and Kim Dae Jung).

The agreements among South Korean political elites were in the interest of each participating party. For the ruling party, to accept the democratic rules of the political game meant the possibility of continuing its government. The use of violence could, in fact, have led to the loss of power. In turn, the opposition party, which was not strong enough to overthrow the government, concluded that by entering into a pact with the authoritarian governments, it had a chance to become a legitimate participant in the political life of the country, and could therefore, ultimately assume power over the state.

The risk of losing political power was a major reason why the elite of the South Korean government and the opposition entered into bilateral negotiations. The logic was that none of the parties would lose all their access and hold on political power and influence. This became the basis of the political pact. As a result, each party received the chance to compete for power. Mutually reduced risk and uncertainty made the reformers of the Democratic Justice Party and the moderate opposition politicians decide to cooperate in the construction of South Korean democracy.

During the change of the political system special roles played by the leaders of the two sides: presidents Chun Doo Hwan and Roh Tae Woo (generals, deriving power from an authoritarian regime), and Kim Young Sam and Kim Dae Jung (leaders of the democratic opposition). South Korean political leaders during their governments 
had to cope with different challenges: Chun Doo Hwan's government was seen as lacking legitimacy during the Fifth Republic, while attempting to liberalize its authoritarianism, while the nascent democratic opposition centered on the New Democratic Party of Korea and a number of pro-democracy social movement organizations challenged Chun's power. During the Roh Tae Woo years, the problems of transition of the political system included such things as settlement of the authoritarian past, and the establishment of civilian control of the military. The Kim Young Sam administration struggled with the problems of fully consolidating democracy. Kim Dae Jung's "Sunshine Policy", that is attempts at reconciliation and reunification of the Korean states, while struggling with an economic crisis put pressure on the government (Saxer 2004: 402403).

Table 1. Profiles of South Korean Political Leaders

\begin{tabular}{|c|c|c|c|c|}
\hline & $\begin{array}{l}\text { Chun } \\
\text { Doo } \\
\text { wan* }\end{array}$ & $\begin{array}{c}\text { Roh } \\
\text { Tae } \\
\text { Woo }\end{array}$ & $\begin{array}{c}\text { Kim } \\
\text { Young } \\
\text { Sam }\end{array}$ & $\begin{array}{l}\text { Kim } \\
\text { Dae } \\
\text { Jung }\end{array}$ \\
\hline $\mathrm{A}$ & 1931 & 1932 & 1927 & 1924 \\
\hline B. & $\begin{array}{c}\text { Kyongsangbuk } \\
\text {-do }\end{array}$ & Kyongsangbuk-do & $\begin{array}{c}\text { Kyongsangnam- } \\
\text { do }\end{array}$ & Chollanam-do \\
\hline C. & KMA & KAW & SNU & KU, UM (Ph.D.) \\
\hline D. & General & General & - & - \\
\hline $\mathrm{E}$. & - & short & long & average \\
\hline $\mathrm{F}$. & - & Government & - & - \\
\hline G. & DJP & DJP & RDP & PPD \\
\hline $\mathrm{H}$. & 1980 & 1988 & 1993 & 1998 \\
\hline I. & $\begin{array}{c}\text { bloodily } \\
\text { suppressed } \\
\text { pro-democracy } \\
\text { uprising } \\
\text { in Kwangju } \\
18-27 \\
.05 .1980 ; \\
\text { struggled } \\
\text { against } \\
\text { the June pro- } \\
\text { democracy } \\
\text { uprising } \\
\end{array}$ & $\begin{array}{c}\text { pro-democracy } \\
\text { declaration; } \\
\text { Nordpolitik }\end{array}$ & $\begin{array}{l}\text { the end of the rule } \\
\text { of the generals }\end{array}$ & Sunshine Policy \\
\hline $\mathrm{J}$. & deficiency & transition of & internalization & consolidation \\
\hline
\end{tabular}




\begin{tabular}{|c|c|c|c|c|}
\hline $\begin{array}{l}\text { of political } \\
\text { legitimacy }\end{array}$ & $\begin{array}{c}\text { the political system; } \\
\text { Northern Policy }\end{array}$ & $\begin{array}{c}\text { of democratic } \\
\text { values; } \\
\text { consolidation } \\
\text { of democracy }\end{array}$ & $\begin{array}{c}\text { of democracy; } \\
\text { Sunshine Policy }\end{array}$ \\
\hline
\end{tabular}

Source: Elaboration by Author (from numerous sources)

* - Direct presidential elections did not cover the period of the rule of Chun Doo Hwan

$\begin{array}{llll}\text { A - } & \text { year of birth } & \text { KMA } & \text { Korean Military Academy } \\ \text { B - } & \text { regional origin } & \text { SNU - } & \text { Seoul National University } \\ \text { C - } & \text { education } & \text { KU - } & \text { Kyunghee University } \\ \text { D - } & \text { military rank } & \text { UM - } & \text { University of Moscow } \\ \text { E - } & \text { parliamentary experience } & \text { DJP - } & \text { Democratic Justice Party } \\ \text { F - } & \text { administrative experience PPD - } & \text { Party of Peace and Democracy } \\ \text { G - } & \text { political party } & \text { RDP - } & \text { Reunification Democracy Party } \\ \text { H - } & \text { year taking office of President } & \\ \text { I - } & \text { political hallmark(s) } & \\ \text { J - } & \text { challenges to the period of the presidency }\end{array}$

\section{Heritage of Confucian Leadership in South Korean Politics}

In traditional Korean society obedience to authority was considered a patriotic virtue. Shaped by a Confucian hierarchical structure of propriety and order, all of society was imprinted with specificity of roles for the family, society and country, where "the guiding spirit of hierarchically arranged virtues is the duty, and each of the virtues is the right and duty at the same time" (Wójcik 1995:24).

Confucian cultural patterns particularly stress the institution of the family, social harmony, respect for authority, respect for education, and political order. In Confucian civilization, the family is the "organizational model for all the other communities and collectives: the state, business, office, branch of the military or even political parties" (Gawlikowski 2001:49). In the Confucian system morality and politics were inseparable, because there was a close relationship between self-interest, and the interests of families, societies, and countries (Kihl 1997: 117-118). The whole of Confucian philosophy of democracy is based on the concept of political stewardship. The Chinese word mu means shepherd (pastor or steward). The ruler is called ren mu (人牧)-"shepherd 
of man." He is a priest of Heaven, entrusted with the duty of political control of the masses (Hsü 1932: 174). The Confucian theory of the rule of the ruler is the father of his people, and his right to rule stems from the order of nature. The most significant feature of the system is centralized Confucian political leadership. It has its roots in the Confucian doctrine, which holds that the sovereign state has its mandate to govern by the will of Heaven, from which the right to exercise power is derived.

In the Confucian Analects, the Chinese word on "zheng" (政), is translated as - rule. Confucius further elaborates that it denotes the rule that is correct, and that which is not correct should be rebuked (Confucius 1979: 114-115). In turn, the leadership (lingdăo / 領導 (领导)) is understood as - those who are to lead or guide. Confucian leadership is based on the personal and socio political order, which emphasizes the interpersonal relationships between superiors (ruler, superior) and subordinate (dependent).

In Confucianism order and social harmony, should be provided by a good, virtuous and righteous ruler, while in Western democracy it is achieved by the supremacy of law. In the traditional Confucian state power was indivisible (Gawlikowski 2009: 92-96). The concept of the Western separation of powers functioning in a liberal democracy introduced a new model of relations and distribution of power in South Korea. South Korean political leaders fought for democratic change in the country, received a democratic constitution, but failed to surrender to democratization. Political leadership in democratizing South Korea still remained authoritarian. The cultural heritage of Confucianism could also be found in the functioning of South Korean political parties based on the pattern of the family and Confucian values. It demonstrated an existing pattern of paternalism. Personalization of political parties determined the South Korean style of governance and leadership. In this Confucian East Asian country, which has existed for centuries, a different traditional understanding of the individual, society and state, as well as the core values of assimilation by Koreans unknown to them before democracy was a very difficult task.

Koreans have always wanted a strong leader responsible for the whole nation. This social expectation had its source in the historical experience from the period of Japanese occupation, as well as in the division of Korea into two states and the Korean 
War. Strong leadership was justified by the South Korean presidents for purposes of maintaining national security of the state in response to the unpredictability of North Korea. Chieftainship party leaders and personalization of power has led to the emergence of South Korea phenomenon called in Korean language daekwonjuui (meaning "rule of a strong hand"). The influence of these two phenomenons promoted a concept of the institution of the presidency as necessitating almost total power (Im 2000: 22; Przeworski 1991:26).

\section{Chun Doo Hwan - The Collapse of the Authoritarian System}

On August 16, 1980, the control of the political authority of the South Korean state was consolidated by the leader of a military coup General Chun Doo Hwan (Eckert et al. 1990: 372-373). The military government of Chun Doo Hwan employed violence, which included the bloody suppression of a pro-democracy uprising in Kwangju. Additionally, the "new military" placed restrictions on freedom of speech, were guilty of human rights violations, dissolved parliament, and banned the activities of opposition political parties. In the period from 1980 to 1983, the level of political repression by the government was intense, and was directed at all those who undertook any activities directed against the authoritarian government (Hyuk 2000: 78).

The executive branch of the Fifth Republic was not subject to any restrictions or controls by other political institutions, and consequently, the South Korean government was consistently represented as a state of lawlessness. Using a policy of prohibition against various political activities, the state conducted operations aimed at incapacitating the opposition from engaging with civil society (Hinton 1983: 59-63). By drawing up so-called "black lists", containing the names of political dissidents, the government sought to eliminate from participation in politics, Kim Young Sam and Kim Dae Jung, the most important leaders of the political opposition.

However, after three years of persecution and repression the political situation in South Korea began to gradually change. Beginning in 1983, there emerged a period of political 
decompression and as a result, there began to form numerous independent, autonomous, pro-democracy civil society organizations (Im 1997: 7-8). The government tolerated all these emerging organizations only if they did not question the legitimacy of the Fifth Republic's authoritarian rule. As a consequence, this movement toward decompression became somewhat of a test of the Fifth Republic's limits of political tolerance.

A retrospective analysis of this period shows that firstly, the decision of President Chun Doo Hwan to open the political system provoked a crisis for authoritarian rule. The liberalization of authoritarianism in South Korea meant a partial opening of the system, but did not yet include free elections, and only consisted of the extension of freedom of speech, assembly and association. It should be noted that the great achievement of the liberalization process was the development of political pluralism and the lifting of bans on political activity by leaders within the opposition.

Secondly, the crisis in the authoritarian system began after the election for the National Assembly in February 1985, when the Democratic Party of New Korea (DPNK) (formed three weeks before the election), openly questioned the authoritarian system. The DPNK became a real catalyst for political activity among Koreans. The elections of February 25, 1985 was, in effect, a national re referendum on the legitimacy of the system Fifth Republic. It turned out that the opposition was able to organize effective and widespread public support for policy changes (Koh 1985: 887).

The DPNK strived to implement its three main policy objectives: the end of military rule, establishment a system of direct presidential elections, and actions leading to national unification. The DPNK exhorted Koreans to mobilize themselves in a fight for democracy (Kim 1986: 68-69). The government's liberalization of the authoritarian structure focused on maintaining the system while improving the political image of President Chun and the ruling DPS. The government expected positive results. However, the decompression brought forth political activity across a broad spectrum of the population, and marked the growth of truly anti- 
authoritarian forces that irrevocably changed the face of the South Korean political scene ${ }^{1}$.

In the period after 1983, the population of South Korea became increasingly aware of the existing problems resulting from the ineffectiveness of the functioning of an authoritarian system. The dissonance between the economic achievements of the government and the introduced by him political changes meant that Koreans understood that the previously used political solutions and lines of argument regarding authoritarian rule as a safeguard of security had become ineffective in overcoming the current social problems.

It should also be emphasized that the drift of the political in the direction of democratization made possible not only by the occurrence of a crisis of authority based on questioned legitimacy, but also due to a crisis of the entire system, which became perceived as being unable to solve the increasingly serious and numerous social problems resulting from the gradually crystallizing of a new political reality in South Korea.

In June 1987 the National Coalition for a Democratic Constitution organized a big rally, which in turn lasted as a democratization uprising from 10 June onward. The uprising was precipitated by the decision of president Chun Doo Hwan to call a cessation of public discussion on the revision of the Constitution. The "June uprising", consisting of widespread and large-scale demostrations, demanded an end to the rule of a military dictatorship. In June a million Koreans attended another national rally called the "peace march". These events were the results of spontaneous and unprecedented mobilization of pro-democracy groups, social movements. As a result, the authoritarian government announced a radical and unexpected concession to the pressures of society and on June 29,1987 , the presidential nominee of the ruling

\footnotetext{
${ }^{1}$ The reason the authoritarian government decided to open up the political process of liberalization was not an instance of a split in its structures, but the confidence and the belief that nothing and no one would be able to threaten the stability of the system. In classic cases of transition, e.g. in Southern Europe or Latin America, systemic change was the result of divisions within the structures of the authoritarian system (mainly between hardliners and softliners). In the case of South Korea, there has been a split in the governing structures of the block, a block, which at the time was homogeneous and united. The elite of the ruling Democratic Justice Party were united not only before liberalization, but also after the process of liberalization had commenced.
} 
party. Roh Tae Woo, announced a pro-democracy declaration, part of which adopted a system of direct presidential elections (Lee 1990: 36-39).

\section{Roh Tae Woo - Leader of in the Period of Democratic Transition}

The great achievement of the opposition was direct presidential elections held on December 16, 1987. However, the election results turned out differently than the opposition had expected. Although June's declaration made possible for approval of a change in the Constitution mandating the conduct of direct presidential elections, the success was also the beginning of the disintegration of opposition. It is a paradox that a plurality of South Korean voters, 36 percent, ultimately chose Roh Tae Woo - the candidate of the ruling party. A large number of voters choose Roh, a former Army general, as a means of guaranteeing stability and security (Lee 1990: 145-148). The political ambitions of Kim Young Sam and Kim Dae Jung resulted in neither of them to defer to the other, and therefore, the opposition votes were split. The two candidates, in effect, divided votes from pro-democratic supporters and social movement organizations. South Korean made a transition through pacts, guarantees and negotiations among elites, making the victory of Roh Tae Woo a victory for the elites with ties to what had been the authoritarian past. The 1987 presidential election, however, should be assessed positively, however, since the Roh Tae Woo did not rely on the power of the power of those who had been associated with Chun's military coup, but was elected through the will of South Koreans voters. It can be stated; consequently, that the prodemocracy declaration of June 29, 1987 was the crowning achievement of Koreans' struggle for democratic change in a country had been dominated by an authoritarian structure since the early 1980s. After the 1987 presidential election South Korea faced the great challenge of building a democracy (Back 1994: 245).

According to the concept of S. P. Huntington, the democratization process consists of four stages: the collapse of authoritarian rule, a transition, consolidation, and the maturing 
of a democratic political order (Shin 1994: 143). Transition is a period of time between something finished and something not yet fully formed, which means that the outcome of the change is a great unknown. The change may in fact lead to the consolidation of a democratic regime or, e.g., to a return to another form of authoritarianism. The democratization process consists of intense political changes (O’Donnell and Schmitter 1986: 63-65). This sometimes entails institutional fluctuations and uncertainty, dynamic conflicts and pervasive political polarization. It is a period characterized by a great dynamism of the interaction between authoritarian leaders seeking ways to stay in power, and the democratic opposition seeking ways to acquire it. Transitions of political systems do not automatically lead to democratic governance, and can be "risky journeys". These "risky journeys" are primarily periods of great uncertainty, with opportunities and hope for democratic change (Schedler 2001: 3).

South Korea during the Roh administration found itself in the face of the great challenges of political and social issues. The first big challenge concerned the establishment of a strong, but flexible leadership for the country. There was justified fear that the strong position of the president could mean a continuation of the dictatorship, because before transition the legislature and the judiciary had not been a real counterweight to the executive branch. The second challenge was the revision of the law, since most of the existing laws were highly restrictive given the attention to the issue of national security. During the administration of Roh Tae Woo many laws were liberalized. The third challenge involved the new government's response to the authoritarian past of the Fifth Republic. The main aim of political reform was to build a new image of the president of the South Korean state and government of the Sixth Republic, which still was seen as an institution dominated by the military. The fourth challenge was the issue of exercising civilian control over the military. The generals Park Chung Hee carried out the military coups in 1961 and 1980 and Chun Doo Hwan constituted a real basis for concern (Kim 1993: 157-158).

The parliamentary elections of April 26, 1988 represented another important political event during the period of transition. The results of these elections were a huge disappointment for all those who predicted another victory of the Democratic Justice Party (DJP) it obtained 34 percent of the votes. An even greater surprise, 
however, was the second place ranking of the Party of Peace and Democracy led by Kim Dae Jung - the party garnered 19.3 percent of the votes cast by South Koreans. The parliamentary elections of 1988 were a turning point, because it meant the end of the parliamentary majority of the ruling party. For the first time in the history of the Republic of Korea, the government party lost its majority in Parliament. Given the previous DJP majorities in parliament, a new electoral verdict was seen as a transfer of legislative power into the hands of the opposition. The winning of 174 seats in parliament by the opposition parties was considered as a great success of this election in terms of democratic transition .The inability to control the parliament by the Roh administration and the results of the hearings conducted by the investigation committee, which exposed the degree of abuse within the Fifth Republic, meant in practice that the government could not no longer control the legislative process. It remains to be emphasized that thanks to the new situation in the Parliament called in Korean, "yoso yadae" that is, a ruling minority and an opposition majority, opposition parties were given the opportunity to limit powers of the president (Kim 1993: 114). Thus the defeat of the ruling DJP forced its political leaders to engage in actions leading to cooperation and political compromise with the opposition.

Among important achievement in the second half of 1988 included the initiative of the opposition parties resulting in a series of parliamentary inquiries that revealed the truth of corruption and numerous abuses of power during the Fifth Republic. A significant political achievement had been the 1987 establishment of a new constitution. As part of the new constitution, the National Assembly regained all its power, which has lost during the two previous authoritarian governments of Park and Chun. The most important constitutional change commanding the start of the South Korean transition was the establishment of a system of direct presidential elections resulting in the implementation of a new series of electoral laws and the extension of powers of the legislative body (Kim 1993: 111-113). Settlement of the authoritarian past the Fifth Republic was yet another great challenge of the new government. In 1988-1989, there was a public debate on the abuse of power by the political elites of the government Chun. The public demanded the compensation for the victims of the uprising in Kwangju. 
During the administration of Roh Tae Woo a variety of reforms were adopted. For example, in March 1989, new legislation was enacted protecting the right of assembly and freedom of speech. The government liberalized restrictions on travel abroad and lifted bans on publication and possession of material on communism and North Korea. Another important achievement of the Roh administration was the establishment of the so-called "Northern Policy". This reform of foreign policy ushered in a policy of openness to engagement with North Korea. The minimized anti-communist education was increasingly replaced by government promoted education on national unification (Kihl 1995: 126).

By the end of the 1980s, the Republic of Korea also had begun to normalize relations with the countries of the former socialist camp. During the administration of Roh Tae Woo established diplomatic relations with many of these countries. The agreement between Poland and the Republic of Korea to establish diplomatic relations was signed in November 1989 in Seoul.

The Olympic Games held in 1988 in Seoul was an event that also contributed to political changes. The Olympic Games proved to be a catalyst for South Korea's first informal contacts with representatives of countries of the former socialist community. The years 1988-1990 were also a period of unprecedented changes in the South Korean Army. The establishment of civilian control over the military was advanced in tandem with the implementation of modernization of the army. In March 1991 the government began another important project, the aim of which was to break the concentration of business created by chaebols (Horowitz 2002: 8789).

No less significant to the process of transition was the formation of the political party system. In the initial period of transition, the existing four-party structure showed a tendency to exacerbate regional conflicts and social antagonisms. Growing disputes and regional feuds certainly did not help with the implementation of the principles of democracy (Huang 1997: 152153). After the parliamentary elections in 1988, the National Assembly was dominated first by the opposition parties, which effectively limited the activities of the government. During the first two years of the Roh administration the ruling party did not have a majority in parliament, which consequently meant no possibility for the government to push through laws that were part of its 
legislative agenda. It was one of the main reasons why in 1990 the chairman of the DJP decided to merge with the Democratic Unification Party of Kim Young Sam and the New Democratic Republican Party of Kim Jong Pil. The merger of these three political parties formed the Democratic Liberal Party. This coalition changed the existing parliamentary phenomenon of yoso yadae. By obtaining a majority in this way, in March 1992, the parliament passed 23 laws. The combination of these three parties made the Roh administration politically able to govern effectively, and also led to the end of the impasse between the government and parliament (Kim 1994: 195).

\section{Kim Young Sam - The First Civilian President}

Undoubtedly, two important political events in 1992 that clearly demonstrated a continuation of democratic change: one was the next parliamentary elections in which the ruling party - the Democratic Liberal Party - again failed to win a parliamentary majority (Bae and Cotton 1993: 178). In 1992, there was also a presidential election. These two elections provided evidence of the internalization of democratic values in South Korean society. Holding the political elite to standards of democratic conduct in both the ruling party and the main opposition party, the pre-election statement from Roh Tae Woo of his establishment of a neutral cabinet, and the army indicating its political neutrality, and the conduct of relatively free and fair elections, were indicative that South Korea's process of democratic consolidation was in progress both in terms of rules and procedures (Sigur 1993: 12-14; Bae 1995: 66-67).

On February 25, 1993 Kim Young Sam took the presidential oath of office thus heralding the birth of the first civilian presidency in 32 years. Kim's presidency marked the end of the rule of generals and testified to the need for the continuation of democratic change. Kim pledged to build a "new Korea", the fight against corruption and revive the economy ${ }^{2}$. Also he asked the Koreans to maintain

\footnotetext{
${ }^{2}$ Despite the fact that Kim Young Sam was the first civilian president for 32 years, he was nonetheless associated with the militarists because in 1990 he merged his party
} 
social discipline and cultivate traditional Korean values (Ahn 1999: 33-36).

Reform of the military was among the most important reforms introduced by the administration of Kim Young Sam, because it strengthened the authority of the Minister of Defense. For the first time since the military coup in 1961, there was civilian control of the South Korean military. From the very beginning of the Kim Young Sam administration, Koreans demanded punishment of those responsible for the brutal suppression of pro-democracy uprising in Kwangju (Cha 1993: 854; Oh 1999: 135-136).

By the end of 1995, in order to eliminate authoritarian past, Kim Young Sam approved a special law under which two former presidents Chun Doo Hwan and Roh Tae Woo and other military men were brought to trial. The arrest and subsequent judgment of the former presidents in a trial whose judicial process was open to the public was unprecedented testimony to the end of military rule in the Republic of Korea.

The obligation to conduct a public declaration of assets of high-ranking government officials, members of the National Assembly, party activists, high-level military and police was a major project to consolidate the young democracy. Establishment of a system of financial transactions under real names was further evidence of the consolidation of democratic change, because for many years elites were allowed to open bank accounts under a fictitious name. These reforms were widely recognized as great achievements of the administration of President Kim Young Sam.

Undoubtedly, an important challenge for the young South Korean democracy was the authoritarianism of President Kim Young Sam. His autocratic presidency in the early phase of democratic consolidation of democracy could be seen by comparing the number of laws of Parliament with a number of presidential decrees and implementation of ministerial level actions during the administration of Kim Young Sam. This strengthened the presidency without the need for competition among political parties, while being in "the shadow of the political" Constitutional Court (Croissant 2002: 19-36).

- the Democratic Unification Party - with the government party - the Democratic Justice Party. 
In South Korea, there were factors that both supported and hindered the consolidation of a democratic political system. The factors supporting consolidation included: ethnic homogeneity, the lack of religious conflict, and the establishment of civilian control over the military ( $\operatorname{Im}$ 1997: 22). In turn, the primary condition hindering consolidation was the weak development of the party system. South Korean public support for systemic changes also led to the gradual emergence of a democratic society. The establishment of a democratic political system abolished barriers to its development after they have been used by authoritarian Fifth Republic (Steinberg 2000: 224-225). Attempts at moving away from authoritarianism were related to, among others, the various forms of self-organized associations among Koreans. Spontaneously creating their own voluntary associations and organizations contributed greatly to the development of a democratic society affecting the consolidation of South Korean democracy, which has since become the "only (one) game in town" (Im 1997: 32).

\section{Kim Dae Jung - A Leader in the Struggle for South Korean Democracy and Author of the Sunshine Policy}

For many years South Korea was ruled by presidents who came from the region of in the southeast (Kyongsang). This situation changed with the next presidential election, which took place in December 1997, when Kim Dae Jung won the election. Kim Dae Jung, a veteran of the struggle for freedom and human rights, originated from the southwest (Cholla) ${ }^{3}$.

It was the first peaceful transfer of power in 50 years of political history; a transfer of power to an opposition party. In his inaugural speech, Kim presented the enormity of the challenges facing his administration. He announced that in order to improve the life of Koreans they would certainly experience "sweat and tears". Kim outlined the three main objectives of his administration:

\footnotetext{
3 Kim Dae Jung ran four times in the presidential elections of 1971, 1987, 1992, and finally in 1997, when he was elected at the age of 73. During his forty-year political career Kim spent approximately 14 years in prisons and detention centers. He repeatedly risked his life to defend the ideals in which he sincerely believed.
} 
to improve the economic situation, to warm relations with North Korea, and to support democratic institutions. Reforming the economic system by Kim Dae Jung coincided with the period of the Asian economic crisis, which was painfully felt by South Koreans during 1997-1998 (Lee 2000: 9-13). As a result of the drastic collapse of the exchange rate of the South Korean won, foreign exchange reserves proved necessary and immediate assistance from international financial institutions (including the International Monetary Fund), proved necessary. This saved the country from economic disaster. Despite the extremely difficult situation, the South Korean economy under the leadership of Kim Dae Jung the situation by the end of 1998 was moving toward stabilization (Friedman 2006: 65-67). By late 1999, the government announced the end of the crisis in the country. Kim Dae Jung aroused both great affection and loyalty among supporters and a mixture of ambivalence or even hostility among his opponents. Struggling for many years under military rule created his charismatic image of a leader seeking to establish freedom and democracy, but also a Korean who desired to unite his beloved homeland. Many political observers agreed that Kim had outstanding political abilities (Kim 2000: 35-41).

From the beginning of his administration Kim Dae Jung consistently sought to realize his political dream of a reconciled and united Korea. In his autobiography he wrote, standing at the Berlin Wall made him realize that the purpose of the rest of his life would be devoted to the study of plans for the unification of my homeland. The "Sunshine Policy" envisioned a peaceful unification of the two Korean states, which since the end of hostilities in 1953, had remained technically at war.

During June 13-15, June 2000 Pyongyang hosted an unprecedented meeting of leaders of the two Korean states, the President of South Korea, Kim Dae Jung, and the Chairman of the National Defense Commission of North Korea, Kim Jong Il. It was historical turn in inter-Korean relations opening the possibility for increased cooperation and the emergence of a hope for Korean reconciliation Koreans. The Korean Summit was a symbol of the success of the political administration of President Kim Dae Jung, policy architects of reconciliation, and inter-Korean cooperation. The meeting, at the highest level of state power of the two Koreas, was a major political event in the history of the divided Korean people. 
After years of mutual hostility and distrust the two Koreas seemed to be opening a new stage in relations oriented toward building reconciliation and mutual trust. The Nobel Peace Prize was awarded to President Kim in 2000. It was not only an expression of international recognition for his efforts in the process of reconciliation between the two Korean states, but an appreciation of his great merits in the process of the formation of South Korean democracy.

Table 2. South Korean Leaders in Presidential Elections (1980-1997)

\begin{tabular}{|c|c|c|c|c|}
\hline LP & $\begin{array}{l}\text { Chun Doo } \\
\text { Hwan* }\end{array}$ & Roh Tae Woo & $\begin{array}{c}\text { Kim Young } \\
\text { Sam }\end{array}$ & $\begin{array}{c}\text { Kim Dae } \\
\text { Jung }\end{array}$ \\
\hline $\begin{array}{c}\text { Date/ } \\
\text { method } \\
\text { of elections }\end{array}$ & $\begin{array}{c}\text { August } 27,1980 \\
\text { Chun elected } \\
\text { president } \\
\text { by the National } \\
\text { Council of } \\
\text { the Union; } \\
\text { February } \\
25,1981 \\
\text { Chun elected } \\
\text { president } \\
\text { by the Electoral } \\
\text { College }\end{array}$ & $\begin{array}{c}\text { December 16, } \\
1987 \\
\text { general direct } \\
\text { elections }\end{array}$ & $\begin{array}{c}\text { December 18, } \\
1992 \\
\text { general direct } \\
\text { elections }\end{array}$ & $\begin{array}{c}\text { December } \\
18,1997 \\
\text { general } \\
\text { direct } \\
\text { elections }\end{array}$ \\
\hline $\begin{array}{l}\text { Number } \\
\text { of votes }\end{array}$ & & 8282738 & 9977332 & 10326275 \\
\hline $\begin{array}{c}\text { Percentage } \\
\text { of votes }\end{array}$ & & $36.6 \%$ & $42.0 \%$ & $40.3 \%$ \\
\hline $\begin{array}{c}\text { Region(s) } \\
\text { with largest } \\
\text { support }\end{array}$ & $\begin{array}{c}\text { Kyongsangbuk- } \\
\text { do }\end{array}$ & $\begin{array}{c}\text { Taegu, } \\
\text { Kyongsangbuk- } \\
\text { do }\end{array}$ & $\begin{array}{c}\text { Pusan, } \\
\text { Kyongsangnam- } \\
\text { do }\end{array}$ & $\begin{array}{c}\text { Kwangju, } \\
\text { Chollanam- } \\
\text { do } \\
\text { Chollabuk- } \\
\text { do } \\
\end{array}$ \\
\hline $\begin{array}{l}\text { Number } \\
\text { of voters }\end{array}$ & & 23066419 & 24095170 & 26042633 \\
\hline $\begin{array}{l}\text { Percentage } \\
\text { of persons } \\
\text { eligible } \\
\text { to vote }\end{array}$ & & $89.2 \%$ & $89.9 \%$ & $80.7 \%$ \\
\hline
\end{tabular}

Source: Elaboration by Author.

* - Direct presidential elections were not conducted during the rule of Chun Doo Hwan. 


\section{Conclusion}

During the democratization of South Korea, the two leaders Kim Young Sam and Kim Dae Jung were generally committed to the democratization of public affairs, civilian control of the military, and post-autoritarian governments, however, they deviated substantially from the principles of democracy in terms of their leadership of their own political parties. "Privatization" of political parties resulted in the crystallization of strong leadership of the parties, acting as a major obstacle to the development of a stable and strong party system and the full consolidation of democracy (Kang 2003: 165-180).

Despite widespread democratic values, in the society of South Korea Confucian values as loyalty and obedience to leaders is still cultivated. South Korea politics has been dominated by traditionally arranged regional arrangements. Strong regional identification of Koreans has made the voters grouped into antagonistic constituencies. In South Korean politics existing divisions are generally not due to the programs of political parties or ideologies, but have been the result of loyalty to political leadership. Although institutions in form have corresponded to patterns found in Western liberal democracies, the functions and modes of action have largely been based on the Korean traditions and culture. Some South Korean dissidents and social critics have observed that the authoritarian order, based on leadership supported by the pillars of loyal political parties and a efficiently functioning bureaucracy, has continued the tradition of a strong executive branch with much power, against the backdrop of attempts to create and refine a "New Korea" and its democracy.

\section{References}

Ahn, Byung Young. 1999, Korea's Democratization, Achievements and Issues, "Koreana", Summer, Vol. 13, No. 2.

Back, Jong Gook. 1994. Election as Transformation: Explaining the Reorganization of a Ruling Coalition, in: ed. D. C. Shin, 
M. H. Zoh, M. Chey, Korea in the Global Wave of Democratization, Seoul.

Bae, Sun Kwang, Cotton, James. 1993. Regionalism in Electoral Politics, in: ed. J. Cotton, Korea under Roh Tae Woo: Democratization, Northern Policy and Inter-Korean Relations, Canberra.

Bae, Sun Kwang. 1995. Continuity or Change: The Voter's Choice in the 1992 Presidential Election, w: J. Cotton, red., Politics and Policy in the New Korean State: From Roh Tae Woo to Kim Young Sam, New York.

Cha, Victor D. 1993. Politics and Democracy under the Kim Young Sam Government, w: "Asian Survey", September, Vol. 31, No. 9.

Confucius. 1979. trans. Din-cheuk Lau. The Analects: The Sayings of Confucius. London.

Croissant, Aurel. 2002. Strong Presidents, Weak Democracy? Presidents, Parliaments and Political Parties in South Korea, "Korea Observer", Spring, Vol. 33, No. 1.

Eckert, Carter J., Lee, Kii Baik, Lew, Young Ick, Robinson, Michael, Wagner, Edward W., 1990. Korea Old and New: A History, Seoul.

Friedman, Amy L. 2006. Political Change and Consolidation, Democracy's Rocky Road In Thailand, Indonesia, South Korea, and Malaysia, New York.

Gawlikowski, Krzysztof. 2001. Jednostka $i$ władza $w$ cywilizacji wschodnioazjatyckiej, w: Korea - Doświadczenia i perspektywy, in: ed. K. Gawlikowski, E. Potocka, Torun.

Gawlikowski, Krzysztof. 2009. Konfucjański model państwa $w$ Chinach, Warszawa.

Hinton, Harold. 1983. Korea under New Leadership: The Fifth Republic, New York.

Horowitz, Shale. 2002. Democratization, Dispersed Interest Groups, and Economic Reforms in South Korea: Understanding the Decline of the "Chaebol Republic", "East Asia", Spring.

Hsü, Leonard Shih Lien. 1932. The Political Philosophy of Confucianism: An Interpretation of the Social and Political Ideas of Confucius, His Forerunners, and His Early Disciples, London.

Huang, Teh Fu. 1997. Party Systems in Taiwan and South Korea, in: ed. L. Diamond, M. F. Plattner, Y. H. Chu, H. M. Tien, 
Consolidating the Third Wave Democracies: Themes and Perspectives, Baltimore, MD \& London.

Im, Hyug Baeg. 1997. Politics of Democratic Transition from Authoritarian Rule in South Korea, in: ed. S. Y. Choi, Democracy in Korea: Its Ideals and Realities, Seoul 1997.

Im, Hyug Baeg. 2000. South Korean Democratic Consolidation in Comparative Perspective, in: ed. L. Diamond, B. K. Kim, Consolidating Democracy in South Korea, Boulder, CO \& London.

Kang, David C. 2003. Regional Politics and Democratic Consolidation in Korea, w: S. S. Kim, Korea's Democratization, Cambridge \& New York.

Kihl, Young Whan. 1995. Democratization and Foreign Policy, in: ed. J. Cotton, Politics and Policy in the New Korean State: From Roh Tae Woo to Kim Young Sam, New York.

Kihl, Young Whan. 1997. The Legacy of Confucian Culture an South Korean Politics and Economics: An Interpretation, in: ed. S. Y. Choi, Democracy in Korea: Its Ideals and Realities, Seoul.

Kim Sunhyuk. 2000. The Politics of Democratization in Korea: The Role of Civil Society, Pittsburgh, PA.

Kim, Byung Kook. 2000. The Politics of Crisis and a Crisis of Politics: The Presidency of Kim Dae-Jung, in: ed. K. D. Oh, Korea Briefing, 1997-1999. Challenges and Change at the Turn of the Century, Armonk, NY.

Kim, Eugene C.I. 1986. South Korea in 1985: An Eventful Year Amidst Uncertainty, "Asian Survey", Vol. 16, No. 1.

Kim, Hak Joon. 1993. New Political Development with a Vision, w: J. Cotton, red., Korea under Roh Tae Woo: Democratization, Northern Policy and Inter-Korean Relations, Canberra.

Kim, Hong Nack. 1993. The 1988 Parliamentary Election in South Korea, in: ed. J. Cotton, Korea under Roh Tae Woo: Democratization, Northern Policy and Inter-Korean Relations, Canberra.

Kim, Yong Ho. 1994. Party Politics and the Process of Democratization in Korea, in: ed. D. C. Shin, M. H. Zoh, M. Chey, Korea in the Global Wave of Democratization, Seoul.

Koh, Byung Chul. 1985. The 1985 Parliamentary Election in South Korea, “Asian Survey”, September 1985, Vol. 25, No. 9. 
Lee, Doo Won. 2000. South Korea's Financial Crisis and Economic Restructuring, in: ed. K. D. Oh, red., Korea Briefing, 1997 1999. Challenges and Change at the Turn of the Century, Armonk, NY.

Lee, Man Woo. 1990. The Odyssey of Korean Democracy: Korean Politics, 1987-1990, New York, Westport, CT \& London.

O’Donnell, Guillermo., Schmitter, Philippe C. 1986. Tentative Conclusions about Uncertain Democracies, in: ed. Transition from Authoritarian Rule: Prospects for Democracy, G. O'Donnell, P. C. Schmitter, L. Whitehead, red., Baltimore, MD \& London.

Oh, John Kie Chiang. 1999. Korean Politics. The Quest for Democratization and Economic Development, Ithaca NY \& London.

Przeworski, Adam. 1991. Democracy and the Market: Political and Economic Reforms in Eastern Europe and Latin America, Cambridge.

Saxer, Carl J. 2004. Generals and Presidents: Establishing Civilian and Democratic Control in South Korea, "Armed Forces \& Society", Vol. 30, No. 3.

Schedler, Andreas. 2001. Taking Uncertainty Seriously: The Blurred Boundaries of Democratic Transition and Consolidation, "Democratization", Winter Vol. 8, No. 4.

Shin, Doh Chull, 1994. On the Third Wave of Democratization. A Synthesis and Evaluation of Recent Theory and Research, "World Politics", 1994, No. 47.

Shin, Il Chul. 1994. First Year of Civilian Government, "Korea Focus", January-February.

Sigur, Christopher. 1993. South Korea and the Triumph of Democracy, in: ed. C. J. Sigur, Korea's New Challenges and Kim Young Sam, New York.

Steinberg, David I. 2000. Continuing Democratic Reform: The Unfinished Symphony, in: ed. L. Diamond, B. K. Kim, red., 2000. Consolidating Democracy in South Korea, Boulder, CO \& London.

Wójcik, Anna I. Konfucjusz, No. 471, Kraków 1995. 